\title{
EKSISTENSI AMIL ZAKAT DI KECAMATAN MEDAN AMPLAS SUMATERA UTARA
}

\author{
Studi Kasus: Di Mesjid Ikhlashiyah, Lingkungan I, Harjosari I
}

\author{
Pangeran Harahap*
}

\begin{abstract}
ABSTRAK
Zakat dalam konsep ajaran Islam, selain sebagai suatu kewajiban bagi umat Islam yang kaya, juga merupakan sebagai salab satu bagian dari aturan jaminan sosial dalam Islam. Dalam rangka mewnjudkan konsep tersebut, ajaran Islam menetapkan satu perangkat pengelola yang harus bertindak secara profesional yang diberi nama dengan Amil Zakat. Di Mesjid Ikblashiyah telah terbentuk. Unit Pengumpul Zakat (UPZ) yang telah terkategori profesional sebab legalitasnya dari pejabat yang berwenang. Pada saat penelitian ini dilakukan tabun 2016 Jumlah murakki yang menjadi penyedia modal bagi kegiatan pengentasan kemiskinan dalam istilah penelitian ini adalah berjumlah sebanyak 398 KK dengan jumlah personalnya sebanyak 1.605 orang. Jumlah dana zakat yang terbimpun dalam bentuk beras sebanyak 1.987,20 kg dan dalam bentuk. uang sebesar Rp. 37.718.300,-. Jumlah asnaf zakat yang tercatat dalam catatan Amil Zakat sebanyak. 159 orang, 133 orang di antaranya mustabik dalam kategori fakir dan miskin. Masingmasing fakir dan miskin memperoleh bagian dalam bentuk uang sebesar R. 237.250,- yang digenapkan dari jumlah sebelumnya R. 237.222,-. Sedangkan dalam bentuk beras masing-masing memperoleh sebesar 12,50 Kg. Dampak ekonomi dari pengelolaan zakat oleh Amil Zakat Masjid Ikblashiyah bagi para asnaf zakat yang tergabung di dalam kelompok fakir dan miskin dengan bagian yang diperoleh oleh masing-masing mereka adalah dibagi kepada dua. Pertama, bagi fakir dan miskin yang tidak punya kegiatan dagang melainkan hanya sebagai konsumer saja, dapat membantu untuk. keperluan berhari raya keluarganya ditambah dengan penambah bagi persediaan pangan mereka. Kedua, bagi fakir dan miskin yang
\end{abstract}

* Penulis adalah Penulis adalah Dosen Universitas Islam Negeri Sumatera Utara, Email: pangeranharahap@uinsu.ac.id 
memiliki usaha dagang kecil-kecilan, bagian zakat mereka itu dapat dipergunakan untuk menambah modal untuk. memajukan usabanya dan karenanya meningkat kesejabteraan ekonominya.

\section{Kata Kunci: Eksistensi, Amil zakat, Mesjid Ikhlashiyah}

\section{Pendahuluan}

Zakat dalam ajaran agama Islam dan dalam keyakinan umat Islam adalah merupakan rukun agama sehingga menjadi salah satu dari rukun Islam yang lima. Zainuddin al-Malibary di dalam kitab "Fath al-Mu'in" menyebutkan bahwa zakat dapat dipungut dari para muzakki secara paksa (Zainuddi, 1979:1). Ini memberi arti bahwa keberadaan, pelembagaan dan pengelolaan zakat itu memiliki arti yang sangat penting dalam ajaran agama Islam. Hal ini bisa dimaklumi, sebab dalam pandangan umum, untuk membangun kesejahteraan masyarakat atau ummat baik untuk kesejahteraan kehidupan dunia maupun untuk kesejahteraan akhirat sekalipun, tentu tidak dapat terlepas dari adanya dan keberadaan dana. Ini salah satu argumen pentingnya zakat yang itu dalam konsep ajaran agama Islam.

Sejak tahun kedua hijriahzakat sebagai suatu kewajiban bagi umat Islam yang kaya dan menjadi salah satu rukun Islam tersebut diwajibkan kepada setiap orang yang beragama Islam apabila padanya telah terpenuhi syarat-syarat wajib zakat itu sebagai berikut: 1. Merdeka, 2. Islam, 3. Baligh dan berakal, 4. Mencukupi satu nisab, 5. Harta tersebut milik sendiri secara sempurna, 6. Sampai haul (Rahman Ritonga dan Zainuddin, 1997: 224).

Bagi orang yang terkategori wajib zakat, tatacara pelaksanaan penunaian kewajiban zakat mereka diatur oleh syariat Islam. Syarat menunaikan zakat itu ada dua, yaitu; pertama adanya niat menyerahkan zakat hartanya. Kedua, menyerahkan kepada orang-orang yang berhak menerimanya (mustahaqqin), yaitu mereka yang termasuk di dalam delapan kelompok manusia (asnaf) seperti yang disebut dalam ayat 60 dari surat atTaubah, yaitu: fakir, miskin, amil, mu'allaf, untuk memerdekakan budak, orang yang berhutang, fisabilillah dan ibnu sabil.

Paling tidak ada dua pondasi dasar yang melandasi pelaksanaan penunaian kewajiban membayar zakat ini dalam konsep ajaran Islam. Pertama, sebagai alat ukur penguji bagi keimanan seorang muslim apakah akan mentaati perintah agama atau mengabaikannya. Kedua, sebagai salah satu bagian dari aturan jaminan sosial dalam Islam. Jaminan sosial di sini maksudnya para kaum duafa dapat tertolong untuk memenuhi kebutuhannya lewat pengelolaan harta zakat secara profesional oleh Amil 
Zakat. Dalam hal ini, penunaian zakat oleh umat Islam dikategorikan sebagai ibadah sosial.

Dari dua pondasi dasar yang melandasi pelaksanaan penunaian kewajiban membayar zakat dalam konsep ajaran Islam seperti disebutkan di atas, hal yang menarik dan menjadi kajian pada penelitian ini adalah dalam hal harta zakat yang dikelola secara profesional sehingga dapat menjadi salah satu bagian dari aturan jaminan sosial. Atas dasar itu maka penelitian ini diberi judul dengan "EKSISTENSI AMIL ZAKAT DI KECAMATAN MEDAN AMPLAS (Studi Kasus Di Mesjid Ikhlashiyah Lingkungan I, Harjosari I)". Lewat judul yang menjadi pilihan peneliti tersebut di atas, akan dicoba untuk digali secara fokus dan mendalam tentang apakah pengelolaan zakat secara profesional itu memiliki potensi untuk mengentaskan kemiskinan bagi masyarakat muslim.

\section{Rumusan Masalah}

Dari paparan mengenai fokus kajian yang telah dikemukakan di atas, maka rumusan masalahnya dibuat dalam bentuk pertanyaan-pertanyaan seperti berikut:

1. Berapa jumlah muzakki dalam catatan Amil Zakat Masjid Ikhlashiyah.

2. Berapa jumlah asnaf zakat yang tercatat dalam catatan Amil Zakat Masjid Ikhlashiyah serta berapa jumlah asnaf fakir dan miskinnya.

3. Berapa jumlah zakat yang terhimpun serta besaran jumlah bagian yang diperoleh oleh masing-masing asnaf dari kalangan fakir dan miskin tersebut.

4. Seperti apa bentuk dampak ekonomi bagi para asnaf zakat fakir dan miskin dengan bagian yang diperoleh oleh masing-masing mereka.

\section{Tujuan Penelitian} berikut:

Adapun yang akan menjadi tujuan dari penelitian ini adalah sebagai

1. Untuk mengetahui berapa banyak muzakki yang mempercayakan penyaluran zakatnya melalui Amil Zakat Masjid Ikhlashiyah, sehingga akan diketahui besaran potensi bagi upaya pengentasan kemiskinan di daerah ini.

2. Untuk mengetahui berapa banyak asnaf zakat dari kalangan fakir dan miskin yang akan memperoleh bagian dari zakat di wilayah ini.

3. Untuk mengetahui besaran bagian masing-masing fakir dan miskin, sehingga akan dapat diketahui potensinya bagi upaya pengenatasan kemiskinan. 
4. Untuk mengetahui dampak ekonomi yang ditimbulkan dari perolehan bagian para mustahik fakir dan miskin dalam rangka upaya pengentasan kemiskinan.

\section{Manfaat Penelitian}

1. Untuk para muzakki dalam rangka mendapatkan informasi bahwa zakat yang mereka berikan melalui Amil Zakat tersebut tersalurkan dengan baik kepada para mustahaknya serta dapat menjadi salah satu bentuk gerakan amal yang berpotensi untuk mengentaskan kemiskinan.

2. Para cendekiawan dan cerdik pandai semakin terbuka luas cara pandangnya bahwa zakat itu jika dikelola secara profesional merupakan dana yang cukup potensial dijadikan sebagai sarana mensejahterakan ummat. Lewat itu pula mereka akan sadar serta semakin besar gairah dan keinginannya untuk membentuk Amil Zakat dan mengelola hartaharta zakat ummat Islam itu secara profesional.

\section{Ruang lingkup dan Setting Penelitian}

Ruang lingkup dan site dari penelitian ini meliputi:1. Jumlah muzakki, 2.Jumlah dan bentuk zakat, 3. Jumlah mustahik, 4. Jumlah bagian masing-masing mustahik, 5. Potensi harta zakat bagi upaya pengentasan kemiskinan di dalam wilayah dan dokumentasi Amil Zakat Masjid Ikhlashiyah yang berdomisili di jalan Garu I, Lingkungan I, Kelurahan Harjosari I, Kecamatan Medan Amplas.

\section{Kerangka Penelitian}

Penelitian ini akan dibangun di atas kerangka pemikiran seperti berikut:

1. Kemiskinan adalah keadaan dimana terjadi kekurangan hal-hal yang biasa untuk dipunyai seperti makanan, pakaian, tempat berlindung dan air minum, hal-hal ini berhubungan erat dengan kualitas hidup . Bentuk kemiskinan ini dapat dikelompokkan kepada tiga, yaitu: a. Kemiskinan Absolut, b. Kemiskinan Relatif, dan c. Kemiskinan Kultural. Ketiga macam kemiskinan ini tidak hanya berdampak bagi para penduduk miskin tetapi juga berdampak bagi warga sekitarnya karena kemiskinan juga dapat meningkatkan tindakan kriminalitas.

2. Ajaran agama Islam menghendaki ummatnya agar hidup dalam kesejahteraan. Salah satu cara yang ditawarkan adalah dengan konsep tolong-menolong (QS, 5:2). Salah satu konsep tolong menolong tersebut adalah dengan cara orang kaya diwajibkan supaya membantu 
yang miskin lewat berzakat. Dorongan supaya gigih untuk mencari kesejahteraan hidup disimbolkan dengan orang kaya yang mau berzakat dimasukkan ke dalam kelompok orang yang menjadi pewaris sorga firdaus (QS, 23: 1-11).

3. Shanon, Spicker, Cheyne, O'Brien dan Belgrave dengan Teori NeoLiberahya mengatakan bahwa kemiskinan merupakan persoalan individual yang disebabkan oleh kelemahan dan pilihan individu yang bersangkutan. Kemiskinan akan hilang sendirinya jika kekuatan pasar diperluas sebesar-besarnya dan pertumbuhan ekonomi dipacu setinggi-tingginya. Secara langsung, strategi penanggulangan kemiskinan harus bersifat residual sementara, dan hanya melibatkan keluarga, kelompok swadaya atau lembaga keagamaan.

4. Pierre Phillipe Rey, Meillassoux, Terry, dan Taylor, menggagas suatu teori tentang Strategi penanganan kemiskinan yang mereka beri nama dengan "Teori artikulasi moda produksi". Teori ini mengenalkan dan menawarkan satu strategi penanganan kemiskinan dengan "person in environtment" dan "person in situation" yang dianalogikan sebagai strategi ikan-kail memberikan keterampilan memancing, menghilangkan dominasi kepemilikan kolam ikan oleh kelompok elit dalam masyarakat, dan mengupayakan perluasan akses pemasaran bagi penjualan ikan.

5. Zakat adalah salah satu bagian dari aturan jaminan sosial melalui lembaga keagamaan Islam. Islam memperkenalkan aturan ini dalam ruang lingkup yang lebih dalam dan lebih luas, yang mencakup segi kehidupan material dan spiritual, seperti jaminan akhlak, pendidikan, jaminan politik, jaminan pertahanan, jaminan pidana, jaminan ekonomi, jaminan kemanusiaan, jaminan kebudayaan dan jaminan sosial (Yusuf Qardawi, 2006: 878-879). Seorang yang tadinya sebagai mustahik zakat, pada tahun-tahun berikutnya dengan berkat usahanya yang sungguh-sungguh yang mungkin saja lewat bantuan zakat dari muzakki kemudian menjadi orang yang penunai zakat. Dengan demikian, zakat itu jika ditunaikan serta dikelola dengan baik maka ia akan berfungsi sebagai bentuk kegiatan tolong-menolong. Dengan kata lain, bahwa zakat adalah merupakan ibadah sosial yang merupakan satu wadah atau sarana yang menjembatani ummat Islam menuju masyarakat yang sejahtera. 


\section{Temuan dan Pembahasan}

\section{Jumlah Muzakki}

Dalam rangka untuk mengetahui potensi modal bagi pengentasan kemiskinan yang bersumber dari dana zakat di satu daerah, maka akan sangat penting tentunya untuk mendapatkan informasi serta untuk mengetahui jumlah besaran dari keseluruhan muzakki yang berkedudukan sebagai penyumbang dana. Sebab, jika telah dapat diketahui berapa besaran jumlah dari para muzakki sebagai penyumbang atau penyedia dana itu, maka akan dapatlah diketahui seberapa besar jumlah dana yang tersedia yang akan dijadikan alat atau potensi untuk mensejahterakan masyarakat miskin tersebut dalam rangka upaya untuk mengentaskan kemiskinan itu.

Pada umumnya di Kecamatan Medan Amplas, dan khususnya Di lingkungan Masjid Ikhlashiyah Lingkungan I Kelurahan Harjosari I, penghimpunan dan pengelolaan zakat itu, baik ia zakat fitrah maupun zakat mal, dilakukan hanya sekali dalam satu tahun. Tepatnya pada 7 hari akhir Ramadhan. Adapun jumlah muzakki serta bentuk dan jumlah zakatnya di tempat ini pada periode penerimaan dan pengelolaan zakat fitrah dan zakat mal tahun 2016 adalah sebagai berikut:

\begin{tabular}{|c|c|c|c|c|c|}
\hline $\mathrm{NO}$ & $\mathrm{N}$ A M A & JL & BERAS & UANG/ORANG & UANG (TOTAL) \\
\hline & KEPALA KELUARGA & KEL & $(\mathrm{Kg})$ & $(\mathrm{Rp})$ & $(\mathrm{Rp})$ \\
\hline 1 & Zamhar Aldy & 5 & & 40.000 & 200.000 \\
\hline 2 & Zulham Wajimin & 4 & 10,80 & & - \\
\hline 3 & Hendri Syahputra & 2 & - & 45.600 & 91.200 \\
\hline 4 & H Amrin Husni Lubis & 5 & 13,50 & & - \\
\hline 5 & Syahril R Siregar & 6 & - & 45.600 & 273.600 \\
\hline 6 & Asman & 5 & - & 45.600 & 228.000 \\
\hline 7 & Hj Nurcahaya Harahap & 3 & 8,10 & & - \\
\hline 8 & Ashari Rangkuti & 2 & - & 45.600 & 91.200 \\
\hline 9 & Magrib Siregar & 5 & - & 45.600 & 228.000 \\
\hline 10 & Edi Effendi Siregar & 4 & 10,80 & & - \\
\hline 11 & Nuria & 2 & - & 45.600 & 91.200 \\
\hline 12 & Zakwan & 7 & 18,90 & & - \\
\hline 13 & Alm. Rodi Sirait & 8 & 21,60 & & - \\
\hline
\end{tabular}




\begin{tabular}{|c|c|c|c|c|c|}
\hline 14 & H. Dahlan Tua Sirait & 6 & 16,20 & & - \\
\hline 15 & Rudi Hermansyah Siregar & 5 & 13,50 & & - \\
\hline 16 & Suheri Ginting & 6 & - & 38.000 & 228.000 \\
\hline 17 & Ahmad Amrullah Lubis & 1 & - & 38.000 & 38.000 \\
\hline 18 & Hasrul Abdi Hasibuan & 5 & - & 45.600 & 228.000 \\
\hline 19 & Dahlan Harahap & 4 & 10,80 & & - \\
\hline 20 & H. Muhammad Ramadhani Lbs & 7 & 18,90 & & - \\
\hline 21 & Alm. Baek Lubis & 3 & 8,10 & & - \\
\hline 22 & Senat Sanjaya & 5 & 13,50 & & - \\
\hline 23 & Latifah Nur & 5 & - & 38.000 & 190.000 \\
\hline 24 & Alfina & 1 & - & & - \\
\hline 25 & H. Abdullah Ari & 2 & 5,40 & & - \\
\hline 26 & Ali Armen Lubis & 2 & - & 41.800 & 83.600 \\
\hline 27 & Khairil Arwan & 4 & 10,80 & & - \\
\hline 28 & Guna Amri & 5 & 13,50 & & - \\
\hline 29 & H. Rasyidin Rasyad & 3 & - & 57.000 & 171.000 \\
\hline 30 & Sabaruddin Siregar & 6 & 16,20 & & - \\
\hline 31 & Pasinem & 1 & - & & - \\
\hline 32 & Hj. Ratna Lubis & 3 & 8,10 & & - \\
\hline 33 & Alm. Amir Hamzah Siregar & 1 & 2,70 & & - \\
\hline 34 & H. Amiruddin Hrp. & 3 & - & 57.000 & 171.000 \\
\hline 35 & H. Naharuddin Lubis & 8 & 21,60 & & - \\
\hline 36 & Masrun & 4 & 10,80 & & - \\
\hline 37 & Abd. Latif Batubara & 4 & 10,80 & & - \\
\hline 38 & Budi Mulyadi & 3 & - & 39.900 & 119.700 \\
\hline 39 & Hj. Niswati Hanim & 3 & - & 45.600 & 136.800 \\
\hline 40 & Haryono & 10 & 27,00 & & - \\
\hline 41 & H. Hasbullah Damanik & 5 & - & 45.600 & 228.000 \\
\hline 42 & Masmelan & 2 & - & 41.800 & 83.600 \\
\hline 43 & Dedi P Singgih & 12 & - & 41.800 & 501.600 \\
\hline 44 & Mutia Syahfitri Lubis & 12 & & 41.800 & 501.600 \\
\hline
\end{tabular}




\begin{tabular}{|c|c|c|c|c|c|}
\hline 45 & $\mathrm{H}$ Alwin & 4 & - & 57.000 & 228.000 \\
\hline 46 & Kel Ir H Alwin Sitorus & 1 & - & & 1.000 .000 \\
\hline 47 & Edi Sunarto & 6 & - & 57.000 & 342.000 \\
\hline 48 & Rosmala Dewi Gultom & 2 & - & 45.600 & 91.200 \\
\hline 49 & Rudi Adnan & 5 & 13,50 & & - \\
\hline 50 & Iskandar Muda Lubis & 4 & 10,80 & & - \\
\hline 51 & Muhammad Tauhid & 1 & - & 380.000 & 380.000 \\
\hline 52 & H. Amransyah & 2 & 5,40 & & - \\
\hline 53 & Chairuddin Batubara & 1 & 2,70 & & - \\
\hline 54 & Hj. Aiwan Rani & 2 & - & 41.800 & 83.600 \\
\hline 55 & M. Hidayat Siregar & 2 & - & 33.000 & 66.000 \\
\hline 56 & H. Jumani & 7 & - & 49.400 & 345.800 \\
\hline 57 & Syawaluddin Nst & 4 & 10,80 & & - \\
\hline 58 & Hj. Arba'iyah Daulay & 3 & - & 41.800 & 125.400 \\
\hline 59 & Martua Matondang & 5 & 13,50 & & - \\
\hline 60 & Muheri Syam Lubis & 1 & - & 41.800 & 41.800 \\
\hline 61 & Syamsul & 5 & 13,50 & & - \\
\hline 62 & H. Aludin Lubis & 4 & 10,80 & & - \\
\hline 63 & Atus Lubis & 3 & 8,10 & & - \\
\hline 64 & Rudi Hariono & 4 & 10,80 & & - \\
\hline 65 & H Asmiruddin & 2 & 5,40 & & - \\
\hline 66 & H Abdul Majid Siregar SH & 3 & 8,10 & & - \\
\hline 67 & Hj Sudarmawarni & 2 & 5,40 & & - \\
\hline 68 & Syafii & 5 & - & 41.800 & 209.000 \\
\hline 69 & Tamba Harahap & 5 & - & 38.000 & 190.000 \\
\hline 70 & Ramon M Siregar & 3 & - & 38.000 & 114.000 \\
\hline 71 & H Baharuddin Siregar & 2 & 5,40 & & - \\
\hline 72 & T Usman Ibrahim & 1 & - & 49.400 & 49.400 \\
\hline 73 & Tri Endi A & 6 & 16,20 & & - \\
\hline 74 & Adnan & 4 & & 38.000 & 152.000 \\
\hline
\end{tabular}




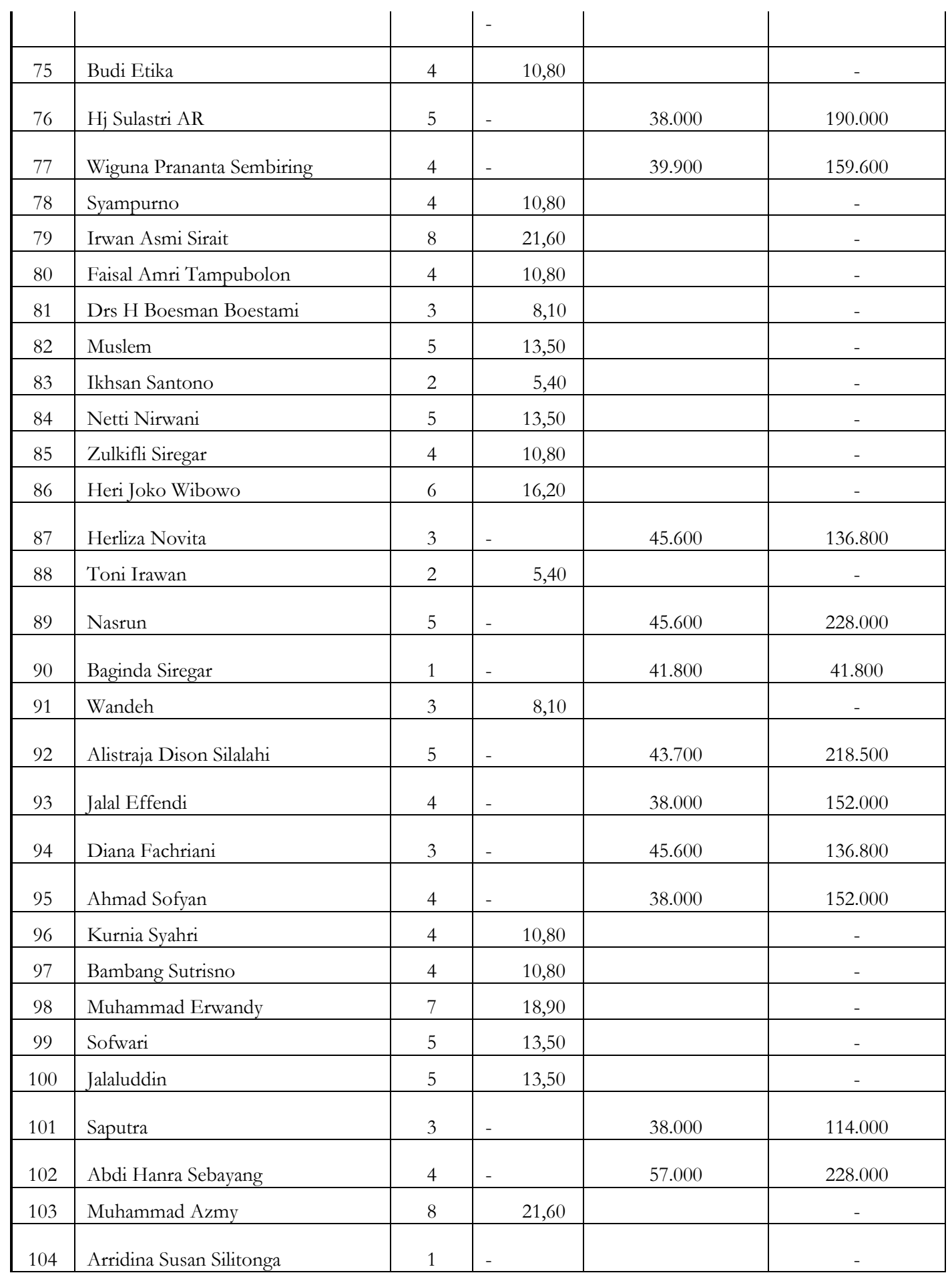




\begin{tabular}{|c|c|c|c|c|c|}
\hline 105 & Masril Halomoan Harahap & 4 & - & 41.800 & 167.200 \\
\hline 106 & H Abdul Aziz Harahap & 3 & 8,10 & & - \\
\hline 107 & Sahlan Siregar & 11 & 29,70 & & - \\
\hline 108 & Yurif Arianto & 4 & 10,80 & & - \\
\hline 109 & Fredi Susanto & 3 & - & 38.000 & 114.000 \\
\hline 110 & $\mathrm{Hj}$ Asma & 1 & - & 41.800 & 41.800 \\
\hline 111 & M Ali & 8 & 21,60 & & - \\
\hline 112 & $\mathrm{Hj}$ Asma & 1 & - & & - \\
\hline 113 & Achmad Zailani & 6 & - & 39.900 & 239.400 \\
\hline 114 & Budi Suwito & 6 & 16,20 & & - \\
\hline 115 & Andi Rahma Tanjung & 6 & 16,20 & & - \\
\hline 116 & Rahmat Frimagus Muslim & 5 & - & 45.600 & 228.000 \\
\hline 117 & Amat Damanik & 3 & - & 38.000 & 114.000 \\
\hline 118 & Miswan Irayadi & 5 & 13,50 & & - \\
\hline 119 & Ahmad Fadil Nasution & 1 & - & 45.600 & 45.600 \\
\hline 120 & Bambang Setiawan & 3 & - & 38.000 & 114.000 \\
\hline 121 & Marito Nasution & 4 & - & 49.400 & 197.600 \\
\hline 122 & Aprilania Rachma & 1 & - & 0 & - \\
\hline 123 & Abdullah Sani & 4 & - & 38.000 & 152.000 \\
\hline 124 & Mulyadi & 3 & - & 38.000 & 114.000 \\
\hline 125 & Mirza Kristo Siregar & 7 & - & 38.000 & 266.000 \\
\hline 126 & Syafruddin Batubara & 3 & 8,10 & & - \\
\hline 127 & Adrian Rahmat Syahputra & 4 & - & 45.600 & 182.400 \\
\hline 128 & M Dedi Tarigan & 4 & - & 38.000 & 152.000 \\
\hline 129 & Indra Bin T Usman & 5 & 13,50 & & - \\
\hline 130 & Kustianto Rahim & 4 & 10,80 & & - \\
\hline 131 & Suripto & 4 & - & 39.900 & 159.600 \\
\hline 132 & Irfan Syahputra & 4 & - & 38.000 & 152.000 \\
\hline 133 & Romi Irwansyah & 3 & - & 57.000 & 171.000 \\
\hline
\end{tabular}




\begin{tabular}{|c|c|c|c|c|c|}
\hline 134 & Budi Armaya & 5 & 13,50 & & - \\
\hline 135 & Ali Hasmar Lubis & 4 & 10,80 & & - \\
\hline 136 & Edi Hidayat & 6 & - & 57.000 & 342.000 \\
\hline 137 & Asman & 5 & 13,50 & & - \\
\hline 138 & Arsad & 5 & 13,50 & & - \\
\hline 139 & Pancha Pradana & 2 & - & 47.500 & 95.000 \\
\hline 140 & Darwinsyah & 3 & 8,10 & & - \\
\hline 141 & Fachruddin & 5 & - & 38.000 & 190.000 \\
\hline 142 & Heriyanto & 3 & - & 41.800 & 125.400 \\
\hline 143 & Armansyah Harahap & 4 & - & 47.500 & 190.000 \\
\hline 144 & Hj Amnah binti Badawin & 3 & 8,10 & & - \\
\hline 145 & H Harsono bin Parmotinoyo & 3 & - & 51.000 & 153.000 \\
\hline 146 & H Syafri & 6 & - & 57.000 & 342.000 \\
\hline 147 & Ayub Khan & 5 & 13,50 & & - \\
\hline 148 & Hasan Basri & 4 & - & 41.800 & 167.200 \\
\hline 149 & Irwan & 6 & - & 38.000 & 228.000 \\
\hline 150 & Muktizar & 4 & - & 47.500 & 190.000 \\
\hline 151 & Syafrielman & 5 & - & 39.900 & 199.500 \\
\hline 152 & Rino Andika S.Sos Mpsi & 6 & - & 57.000 & 342.000 \\
\hline 153 & Ali Yassanip & 2 & - & 41.800 & 83.600 \\
\hline 154 & Isnah & 1 & - & & - \\
\hline 155 & $\mathrm{Hj}$ Sutarni & 1 & - & 45.600 & 45.600 \\
\hline 156 & Herizal & 3 & - & 41.800 & 125.400 \\
\hline 157 & Dicky Chandra Putra & 4 & 10,80 & & - \\
\hline 158 & $\mathrm{Hj}$ Ani & 1 & 2,70 & & - \\
\hline 159 & H Nasir Chandra & 5 & 13,50 & & - \\
\hline 160 & H Ilham & 7 & 18,90 & & - \\
\hline 161 & H Muhammad Yasin & 6 & 16,20 & & - \\
\hline 162 & Ismail & 2 & 5,40 & & - \\
\hline 163 & Amar Ma'ruf Lubis & 5 & 13,50 & & - \\
\hline
\end{tabular}




\begin{tabular}{|c|c|c|c|c|c|}
\hline 164 & Boy Charli Damanik & 3 & 8,10 & & - \\
\hline 165 & N Gozali Siregar & 5 & - & 39.900 & 199.500 \\
\hline 166 & Muhammad Saring & 7 & - & 38.000 & 266.000 \\
\hline 167 & Syafii Junaidi & 3 & - & 49.400 & 148.200 \\
\hline 168 & Irsan Muda Siregar & 6 & 16,20 & & - \\
\hline 169 & Rahmat Rezeki & 4 & 10,80 & & - \\
\hline 170 & Fahrizal & 6 & - & 53.200 & 319.200 \\
\hline 171 & Ratno & 11 & - & 41.800 & 459.800 \\
\hline 172 & Mesrawati Harahap & 4 & 10,80 & & - \\
\hline 173 & Tiasno & 5 & - & 41.800 & 209.000 \\
\hline 174 & Ridho Ramadhan & 2 & - & 41.800 & 83.600 \\
\hline 175 & Ayub Syahputra & 3 & 8,10 & & - \\
\hline 176 & Herwira Lubis & 4 & - & 41.800 & 167.200 \\
\hline 177 & H Amrul Pulungan & 7 & 18,90 & & - \\
\hline 178 & Muhammad Nuh & 3 & - & 38.000 & 114.000 \\
\hline 179 & Hendrik & 4 & - & 38.000 & 152.000 \\
\hline 180 & M Ali Nurdin & 4 & 10,80 & & - \\
\hline 181 & Nasril & 5 & 13,50 & & - \\
\hline 182 & Riswan Juniansyah & 5 & 13,50 & & - \\
\hline 183 & Mahlan & 3 & 8,10 & & - \\
\hline 184 & Doni Sahputra & 5 & 13,50 & & - \\
\hline 185 & Nanang Edy Pranacitra & 3 & - & 41.800 & 125.400 \\
\hline 186 & Umbrok & 5 & - & 38.000 & 190.000 \\
\hline 187 & Iwan Zulkifli & 2 & - & 38.000 & 76.000 \\
\hline 188 & H Hamdan Lubis & 5 & - & 45.600 & 228.000 \\
\hline 189 & Erman Fauzi & 8 & - & 57.000 & 456.000 \\
\hline 190 & Khairuddin Harahap & 4 & 10,80 & & - \\
\hline 191 & Sulaiman Siregar & 5 & - & 45.600 & 228.000 \\
\hline 192 & Satria Hasyim Pane & 4 & 10,80 & & - \\
\hline 193 & Surianto bin Wagimen & 4 & - & 43.700 & 174.800 \\
\hline
\end{tabular}




\begin{tabular}{|c|c|c|c|c|c|}
\hline 194 & Muhammad Lamri & 4 & 10,80 & & - \\
\hline 195 & Fauzi Adrian & 5 & 13,50 & & - \\
\hline 196 & Effendi Makmur Pane & 6 & 16,20 & & - \\
\hline 197 & Muhammad Yusuf bin Kardi & 5 & 13,50 & & - \\
\hline 198 & Dedy Kesuma & 3 & - & 41.800 & 125.400 \\
\hline 199 & H A Taufik Lubis & 6 & 16,20 & & - \\
\hline 200 & Alm Husin Lubis & 4 & 10,80 & & - \\
\hline 201 & Utiman & 5 & - & 57.000 & 285.000 \\
\hline 202 & Syamsuardi & 4 & - & 39.900 & 159.600 \\
\hline 203 & Soegiarto S & 2 & 5,40 & & - \\
\hline 204 & Yusrizal & 2 & - & 38.000 & 76.000 \\
\hline 205 & Ir Samsul Chair & 5 & 13,50 & & - \\
\hline 206 & Elianto & 4 & 10,80 & & - \\
\hline 207 & Lilik Suryadi & 4 & - & 41.800 & 167.200 \\
\hline 208 & Sanusi Lubis & 7 & - & 41.800 & 292.600 \\
\hline 209 & Alfonso Dehan Lubis & 4 & - & 41.800 & 167.200 \\
\hline 210 & Adrizal & 3 & - & 57.000 & 171.000 \\
\hline 211 & Bernard & 4 & - & 57.000 & 228.000 \\
\hline 212 & Irwan Syahputra & 4 & - & 45.600 & 182.400 \\
\hline 213 & Abd Razak & 2 & - & 45.600 & 91.200 \\
\hline 214 & Alm H Chaidir Ending & 2 & - & 53.200 & 106.400 \\
\hline 215 & M Fathul Falah & 3 & - & 57.000 & 171.000 \\
\hline 216 & Rizky Susanty & 1 & - & & - \\
\hline 217 & M Nasib & 3 & 8,10 & & - \\
\hline 218 & Ade Irawan Damanik SH & 4 & - & 41.800 & 167.200 \\
\hline 219 & Sutrisno & 4 & 10,80 & & - \\
\hline 220 & Edi Santoso & 6 & - & 38.000 & 228.000 \\
\hline 221 & Minarsih & 1 & - & & - \\
\hline 222 & Dito Santoso & 1 & - & & - \\
\hline 223 & Ossy Syahputra & 3 & - & 38.000 & 114.000 \\
\hline
\end{tabular}




\begin{tabular}{|c|c|c|c|c|c|}
\hline 224 & LM Sogdan Siregar & 5 & 13,50 & & - \\
\hline 225 & Junaidi Abdillah & 4 & - & 45.600 & 182.400 \\
\hline 226 & Syawaluddin Matondang & 2 & - & 49.400 & 98.800 \\
\hline 227 & Abd Rahman Said SH & 2 & - & 47.500 & 95.000 \\
\hline 228 & M Idris & 5 & 13,50 & & - \\
\hline 229 & Santoso Deddy Palguna & 4 & - & 47.500 & 190.000 \\
\hline 230 & Washington Marpaung & 4 & 10,80 & & - \\
\hline 231 & Joko Rahayu & 3 & 8,10 & & - \\
\hline 232 & Budi Harianto & 4 & - & 38.000 & 152.000 \\
\hline 233 & Sudiono & 5 & 13,50 & & - \\
\hline 234 & Nabilia Assyifa & 3 & 8,10 & & - \\
\hline 235 & Ilham Ritonga & 6 & 16,20 & & - \\
\hline 236 & Ulumudin & 6 & - & 38.000 & 228.000 \\
\hline 237 & Supardi & 4 & 10,80 & & - \\
\hline 238 & Hj Tengku Aisyah & 1 & - & 41.800 & 41.800 \\
\hline 239 & Monang Siregar & 5 & 13,50 & & - \\
\hline 240 & H Hamid Syarifuddin Lubis & 6 & 16,20 & & - \\
\hline 241 & Asharuddin & 5 & - & 49.400 & 247.000 \\
\hline 242 & Praditya Yoga Sugama & 4 & 10,80 & & - \\
\hline 243 & Reny Santy & 1 & - & 38.000 & 38.000 \\
\hline 244 & Aulia Hidaya Ritonga & 2 & 5,40 & & - \\
\hline 245 & Ismail Fahmi Siregar & 2 & 5,40 & & - \\
\hline 246 & M Idris & 1 & - & & - \\
\hline 247 & Rasyad Siregar & 4 & 10,80 & & - \\
\hline 248 & Tanzil Enda Hakim Lubis & 4 & - & 51.300 & 205.200 \\
\hline 249 & M Jahangir & 4 & - & 38.000 & 152.000 \\
\hline 250 & Zakaria & 5 & 13,50 & & - \\
\hline 251 & Miftahul Fauzi & 4 & - & 38.000 & 152.000 \\
\hline 252 & H Dalis Daulay & 6 & 16,20 & & - \\
\hline 253 & Abd Munir & 5 & 13,50 & & - \\
\hline 254 & Masliana Pohan & 5 & 13,50 & & - \\
\hline
\end{tabular}




\begin{tabular}{|c|c|c|c|c|c|}
\hline 255 & Azman Syahputra Siregar & 3 & - & 45.600 & 136.800 \\
\hline 256 & Marzuki Halomoan Matondang & 4 & - & 41.800 & 167.200 \\
\hline 257 & Wahyudi Kurniawan & 4 & 10,80 & & - \\
\hline 258 & Asmah binti HA Manan & 5 & - & 38.000 & 190.000 \\
\hline 259 & Nur Arfian & 5 & - & 45.600 & 228.000 \\
\hline 260 & Budi Hartono & 3 & 8,10 & & - \\
\hline 261 & Faisal Amry Pohan & 4 & - & 45.600 & 182.400 \\
\hline 262 & Ashadi Yamin Nasution & 4 & 10,80 & & - \\
\hline 263 & Almira Alodia & 3 & 8,10 & & - \\
\hline 264 & Suparman & 4 & 10,80 & & - \\
\hline 265 & Hendra Gunawan Siregar & 4 & - & 43.700 & 174.800 \\
\hline 266 & Khairunsyah Putra & 3 & 8,10 & & - \\
\hline 267 & $\mathrm{Hj}$ Soriani Rambe BA & 7 & 18,90 & & - \\
\hline 268 & Indra Gunawan & 3 & 8,10 & & - \\
\hline 269 & Edy Syafrizal Lubis & 4 & - & 41.800 & 167.200 \\
\hline 270 & Dody Irwansyah Damanik & 6 & - & 39.900 & 239.400 \\
\hline 271 & Martua Harahap & 4 & 10,80 & & - \\
\hline 272 & Suparno & 8 & - & 38.000 & 304.000 \\
\hline 273 & Dendri Eko Putra & 6 & 16,20 & & - \\
\hline 274 & Nur Azizah & 5 & - & 45.600 & 228.000 \\
\hline 275 & Komrud Zaman Harahap & 4 & 10,80 & & - \\
\hline 276 & Wahyu Wiriyanto & 4 & - & 45.600 & 182.400 \\
\hline 277 & Hendri & 3 & 8,10 & & - \\
\hline 278 & Abdul Rahim & 4 & - & 41.800 & 167.200 \\
\hline 279 & M Isa Pasaribu & 9 & - & 38.000 & 342.000 \\
\hline 280 & Audi Bukman Pasaribu & 4 & - & 39.900 & 159.600 \\
\hline 281 & Makmur & 6 & - & 47.500 & 285.000 \\
\hline 282 & Ngadikun & 3 & - & 41.800 & 125.400 \\
\hline 283 & Syaiful Bahri & 2 & 5,40 & & - \\
\hline 284 & Trimo & 3 & - & 38.000 & 114.000 \\
\hline
\end{tabular}




\begin{tabular}{|c|c|c|c|c|c|}
\hline 285 & Herman Syahputra & 5 & - & 45.600 & 228.000 \\
\hline 286 & Hendrik Halomoan Harahap & 3 & - & 38.000 & 114.000 \\
\hline 287 & Norma & 1 & - & 41.800 & 41.800 \\
\hline 288 & Razial & 4 & - & 39.900 & 159.600 \\
\hline 289 & Rustam Effendi & 5 & - & 57.000 & 285.000 \\
\hline 290 & Banir Siregar & 5 & 13,50 & & - \\
\hline 291 & Hening Suhartono & 1 & - & 41.800 & 41.800 \\
\hline 292 & Abdul Saleh Hasibuan & 3 & - & 57.000 & 171.000 \\
\hline 293 & Drs HM Kifrawi MA & 3 & 8,10 & & - \\
\hline 294 & Zulkarnaen & 9 & 24,30 & & - \\
\hline 295 & Ismul Choir & 5 & 13,50 & & - \\
\hline 296 & Linda Batubara & 4 & - & 57.000 & 228.000 \\
\hline 297 & Mukrisian & 2 & - & 41.800 & 83.600 \\
\hline 298 & Harry Kurniawan N & 7 & - & 38.000 & 266.000 \\
\hline 299 & Muhammad Fauzy & 1 & - & 38.000 & 38.000 \\
\hline 300 & Lina Mayapuri & 1 & - & 0 & - \\
\hline 301 & Fachmi Humala Nasution & 5 & 13,50 & & - \\
\hline 302 & Suprayetno & 5 & 13,50 & & - \\
\hline 303 & Zulkifli & 6 & - & 38.000 & 228.000 \\
\hline 304 & Syuhyar Syukri Matondang & 4 & - & 39.900 & 159.600 \\
\hline 305 & Supriyadi & 3 & 8,10 & & - \\
\hline 306 & Bayu Eka Setiawan & 3 & - & 38.000 & 114.000 \\
\hline 307 & Sugiman & 5 & 13,50 & & - \\
\hline 308 & Riyad Fitrah & 3 & - & 38.000 & 114.000 \\
\hline 309 & Yulian Badry & 4 & 10,80 & & - \\
\hline 310 & Maryadi & 5 & 13,50 & & - \\
\hline 311 & Bob Haris Damanik & 5 & 13,50 & & - \\
\hline 312 & Nurhayati Siregar & 3 & - & 38.000 & 114.000 \\
\hline 313 & Hj Ratna Delima Lubis & 6 & 16,20 & & - \\
\hline 314 & Hj Dahnely & 4 & & 38.000 & 152.000 \\
\hline
\end{tabular}




\begin{tabular}{|c|c|c|c|c|c|}
\hline & & & - & & \\
\hline 315 & Rifai Harahap & 3 & - & 45.600 & 136.800 \\
\hline 316 & Ponijah & 2 & - & 41.800 & 83.600 \\
\hline 317 & Ahmad Khusyairi Lubis & 3 & - & 43.700 & 131.100 \\
\hline 318 & Benny Hermawan & 4 & - & 38.000 & 152.000 \\
\hline 319 & Mushartayati Harahap & 3 & - & 38.000 & 114.000 \\
\hline 320 & Verasani Lomansyah & 3 & - & 45.600 & 136.800 \\
\hline 321 & Junaidi & 5 & - & 38.000 & 190.000 \\
\hline 322 & Rudi Harman Harahap & 6 & - & 38.000 & 228.000 \\
\hline 323 & Soewito & 7 & - & 38.000 & 266.000 \\
\hline 324 & Budiawan & 5 & - & 41.800 & 209.000 \\
\hline 325 & Muliyadi Basuki & 6 & - & 45.600 & 273.600 \\
\hline 326 & Firmansyah P & 6 & 16,20 & 38.000 & 228.000 \\
\hline 327 & Hj Dewiana Siregar & 4 & 8,10 & 45.600 & 45.600 \\
\hline 328 & Armansyah Batubara & 4 & - & 43.700 & 174.800 \\
\hline 329 & Misran Batubara & 2 & - & 38.000 & 76.000 \\
\hline 330 & Nursiah & 2 & - & 38.000 & 76.000 \\
\hline 331 & M Balian Nasution & 6 & - & 57.000 & 342.000 \\
\hline 332 & Abdul Rahmad Baleo Harahap & 4 & - & 38.000 & 152.000 \\
\hline 333 & Doni Asmon & 8 & - & 41.800 & 334.400 \\
\hline 334 & Ayumi Apas & 1 & - & & - \\
\hline 335 & H Alfian Helmi & 3 & - & 57.000 & 171.000 \\
\hline 336 & Satria Hadiwijaya Putra & 7 & - & 49.400 & 345.800 \\
\hline 337 & Muhammad Hidayat & 3 & - & 47.500 & 142.500 \\
\hline 338 & Suhal Doni Ivantho & 6 & - & 57.000 & 342.000 \\
\hline 339 & Herry Prima & 5 & - & 38.000 & 190.000 \\
\hline 340 & M Ari Susilo & 1 & - & 41.800 & 41.800 \\
\hline
\end{tabular}




\begin{tabular}{|c|c|c|c|c|c|}
\hline 341 & Kisno Rakawasi & 5 & - & 38.000 & 190.000 \\
\hline 342 & Fajar Aulia & 4 & - & 51.300 & 205.200 \\
\hline 343 & $\mathrm{Hj}$ Sumarsih & 3 & 8,10 & & - \\
\hline 344 & Rudi Atmaja & 5 & 13,50 & & - \\
\hline 345 & Budiono & 5 & 13,50 & & - \\
\hline 346 & Hj Nina Erwina Siregar & 3 & - & 0 & - \\
\hline 347 & Ramiadi & 7 & - & 45.600 & 319.200 \\
\hline 348 & Pipi Rahmadani & 4 & - & 38.000 & 152.000 \\
\hline 349 & Harianto & 9 & 24,30 & & - \\
\hline 350 & Hasan Basri & 3 & 8,10 & & - \\
\hline 351 & Indra Kusuma & 5 & - & 49.400 & 247.000 \\
\hline 352 & Yudha Dharma Putra & 4 & 10,80 & & - \\
\hline 353 & Nico Hermawan & 4 & - & 57.000 & 228.000 \\
\hline 354 & Amelia Novayanti & 3 & - & 49.400 & 148.200 \\
\hline 355 & Irwani Wisu Dewi & 1 & - & 49.400 & 49.400 \\
\hline 356 & Kasiono & 5 & - & 43.700 & 218.500 \\
\hline 357 & Maharani Utami & 1 & - & & - \\
\hline 358 & Medisyah Putra & 2 & - & 38.000 & 76.000 \\
\hline 359 & M Yusuf & 5 & - & 41.800 & 209.000 \\
\hline 360 & Syafiuddin Latif & 5 & 13,50 & & - \\
\hline 361 & M Hasbullah Siregar & 2 & - & 41.800 & 83.600 \\
\hline 362 & Harri Susanto & 1 & - & 57.000 & 57.000 \\
\hline 363 & Sofyan Siregar & 4 & 10,80 & & - \\
\hline 364 & Juanda & 5 & 13,50 & & - \\
\hline 365 & Rizal Fitra Abdullah & 1 & 2,70 & & - \\
\hline 366 & Rudianto & 5 & - & 41.800 & 209.000 \\
\hline 367 & Nardi AS & 2 & - & 57.000 & 114.000 \\
\hline 368 & Aris Munandar & 2 & 5,40 & & - \\
\hline 369 & Suyatno & 3 & - & 38.000 & 114.000 \\
\hline
\end{tabular}




\begin{tabular}{|c|c|c|c|c|c|}
\hline 370 & Ahmad Syauqi & 5 & 13,50 & & - \\
\hline 371 & Sukirmanto & 3 & 8,10 & & - \\
\hline 372 & Yusrini Elvina Sari Siregar & 1 & - & 39.900 & 39.900 \\
\hline 373 & Syahrial Efendi Harahap & 3 & - & 39.900 & 119.700 \\
\hline 374 & M Taufik & 3 & 8,10 & & - \\
\hline 375 & Wahyu Nugroho & 2 & - & 41.800 & 83.600 \\
\hline 376 & Ardiansyah & 3 & 8,10 & & - \\
\hline 377 & Suprayogi Adetya Putra & 5 & - & 38.000 & 190.000 \\
\hline 378 & M Hafizh & 3 & 8,10 & & - \\
\hline 379 & Surya Darma Syahputra & 4 & - & 47.500 & 190.000 \\
\hline 380 & Ismadiah Lubis & 3 & - & 41.800 & 125.400 \\
\hline 381 & M Dahris & 3 & - & 41.800 & 125.400 \\
\hline 382 & Adi Junior Lubis & 3 & - & 54.600 & 163.800 \\
\hline 383 & Linda Batubara & 4 & - & 45.600 & 182.400 \\
\hline 384 & Rafik Amidi Lubis & 1 & - & 38.000 & 38.000 \\
\hline 385 & Heryansyah & 4 & 10,80 & & - \\
\hline 386 & Ahmad Hamonangan Siregar & 4 & - & 38.000 & 152.000 \\
\hline 387 & Ramadhani & 5 & - & 38.000 & 190.000 \\
\hline 388 & Raswan & 5 & - & 38.000 & 190.000 \\
\hline 389 & Adi Ahmadi & 3 & - & 45.600 & 136.800 \\
\hline 390 & Budi Rustandi & 4 & - & 38.000 & 152.000 \\
\hline 391 & Rizky Ari Sandi & 2 & 5,40 & & - \\
\hline 392 & Khairuddin Nur Damanik & 5 & - & 38.000 & 190.000 \\
\hline 393 & Topan Hirfan & 5 & - & 38.000 & 190.000 \\
\hline 394 & Deny Julia & 2 & - & 38.000 & 76.000 \\
\hline 395 & M Hafis Assalam Nasution & 6 & 16,20 & & - \\
\hline 396 & Siti Amnah & 6 & - & 38.000 & 228.000 \\
\hline 397 & Deviana & 3 & - & 38.000 & 114.000 \\
\hline 398 & Alfanni Hasmi SH & 2 & & 53.200 & 106.400 \\
\hline
\end{tabular}




\begin{tabular}{|l|l|l|l|l|l|} 
& & - & & \\
\hline & JUMLAH & 1605 & $1.987,20$ & & $37.718 .300^{1}$ \\
\hline
\end{tabular}

Sumber: Buku Dokumentasi Amil Zakat Mesjid Ikhlashiyah Tahun 2016)

Dari data dalam bentuk tabel terpapar di atas, maka keadaan jumlah muzakki dan dana zakat terhimpun dapat diketahui dengan simpulan sebagai berikut:

1. Jumlah muzakki (para wajib zakat) yang menjadi pemberi dan penyedia modal bagi kegiatan pengentasan kemiskinan dalam istilah penelitian ini adalah berjumlah sebanyak 398 Kepala Keluarga (KK) dengan jumlah individu-individu atau personal dari para muzakkinya berjumlah sebanyak 1.605 orang.

2. Jumlah dana zakat dalam bentuk beras sebanyak $1.987,20 \mathrm{~kg}$ dan dalam bentuk uang sebesar Rp. 37.718.300,-.

Jumlah muzakki tersebut di atas sebagai jumlah pemberi modal serta jumlah dana zakat yang terhimpun bagi upaya pengentasan kemiskinan ini, tentu dengan sangat jelas merupakan satu jumlah yang sangat potensial bagi upaya pengentasan kemiskinan di daerah ini, terutama jika dibandingkan dengan jumlah para mustahik (orang-orang yang berhak untuk menerima harta zakat).

\section{Mustahik (Penerima) Zakat}

Adapun jumlah keseluruhan dari mustahik (penerima) zakat pada wilayah Badan Amil Zakat Masjid Ikhlashiyah Lingkungan I Kelurahan Harjosari I Kecamatan Medan Amplas ini adalah berjumlah sebanyak 159 (seratus lima puluh sembilan) orang. Mereka terdiri dari; a. fakir, b. miskin, c. muallaf, d. fisabilillah, dan e. amil zakat. Khusus asnaf atau mustahik zakat dari kelompok fakir dan miskin sebagai bagian dari upaya pengentasan kemiskinan sebagaimana yang menjadi tema utama dalam penelitian ini, mereka adalah berjumlah sebanyak 133 (seratus tiga puluh tiga) orang.

Para mustahik di atas, oleh Badan Amil Zakat Masjid Ikhlashiyah dipilih dan diambil dari dua kelompok kelas ekonomi. Kelompok pertama, terdiri dari orang-orang yang ekonominya berada di bawah garis kemiskinan dan tidak punya pekerjaan dan usaha tetap. Sedang kelompok kedua, mereka adalah terdiri dari orang-orang yang tingkat ekonominya sudah pra sejahtera dan punya usaha kecil-kecilan namun sangat 
membutuhkan dana modal tambahan untuk meningkatkan hasil usahanya (Wawancara Amil Zakat Mesjid Ikhlashiyah). Dari dua macam kelompok mustahik yang disebutkan di atas, yang terbanyak atau yang paling mendominasi dari mereka adalah kelompok pertama. Sedangkan kelompok kedua yaitu orang-orang yang tingkat ekonominya sudah pra sejahtera dan punya usaha kecil-kecilan bilangannya sangat sedikit.

\section{Kesimpulan}

Dari hasil kerja penelitian yang peneliti lakukan mulai dari pengumpulan data sampai dengan pengolahan dan analisis data, maka peneliti sampai kepada kesimpulan sebagai berikut:

1. Jumlah muzakki (wajib zakat) yang menjadi pemberi modal bagi kegiatan pengentasan kemiskinan dalam istilah penelitian ini adalah sebanyak 398 Kepala Keluarga (KK) dengan jumlah individu muzakkinya sebanyak 1.458 orang.

2. Jumlah asnaf zakat yang tercatat dalam catatan Amil Zakat sebanyak 159 orang. Jumlah asnaf fakir dan miskinnya sebanyak 133 orang.

3. Jumlah harta zakat yang terhimpun dan dijadikan sebagai modal (yang menjadi potensi) untuk kegiatan dan upaya pengentasan kemiskinan di daerah ini adalah sebesar: a. dalam bentuk beras sebanyak 1.987,20 $\mathrm{kg}$, dan b. dalam bentuk uang sebesar Rp. 37.718.300,- (tiga puluh tujuh juta tujuh ratus depalapn belas ribu tiga ratus rupiah). Masingmasing fakir dan miskin yang berjumlah 133 orang memperoleh bagian dalam bentuk uang sebesar Rp. 237.250,- Sedangkan dalam bentuk beras masing-masing memperoleh sebesar 12,50 Kg.

4. Dampak ekonomi dari pengelolaan zakat oleh Amil Zakat Masjid Ikhlashiyah bagi para asnaf zakat yang tergabung di dalam kelompok fakir dan miskin dengan bagian yang diperoleh oleh masing-masing mereka adalah dibagi kepada dua. Pertama, bagi fakir dan miskin yang tidak punya kegiatan dagang melainkan hanya sebagai konsumer saja, dapat membantu untuk keperluan berhari raya keluarganya ditambah dengan penambah bagi persediaan pangan mereka. Kedua, bagi fakir dan miskin yang memiliki usaha dagang kecil-kecilan, bagian zakat mereka itu dapat dipergunakan untuk menambah modal untuk memajukan usahanya dan karenanya meningkat kesejahteraan ekonominya. 


\section{DAFTAR PUSTAKA}

Ahmad Hasymi Beik, Mukbtar al- Ahadis an-Nabawiyah, (Surabaya: Muhammad bin Ahmad bin Subhan, tt.).

A. Rahman Ritonga dan Zainuddin, Fiqh Ibadah, Jakarta: Gaya Media Pratama, 1997).

Dewan Redaksi Ensiklopedi Islam, Ensiklopedi Islam, jilid 5, Jakarta: Ichtiar Baru van Hoeve, 1997).

Fakhruddin al-Razi, Al-Tafsir al-Kabir, jilid 16, (Beirut: Dar al-Kutub alIlmiah, 1990)

Ibn Arabi, Abkam al-Qur'an, Jilid 2, (Beirut: Dar al-Jil,1987)

Muhammad Fuad Abd al-Baqi, Al-Mu'jam al-Mufahrasy li Alfaz̧ Alquran alKarim, (Ttp.: Dar al-Fikr, 1401 H./1981 M.)

Muhammad Ibn Jarir at-Thabari, Jami' al-Bayan fi Tafsir al-Qur'an, (Mesir: Al-Halabi, 1954)

Muhammad Jamaluddin al-Qasimi, Tafsir al-Qasimi, Juz 8, (Ttp.: Dar alIhya, tt.)

Muhammad Said Tanthowi, At-Tafsir al-Wasit li Alquran al-Karim, Jilid 6, (Mesir: Dar an-Nahdhah, 1998)

Sayyid Sabiq, Figh al-Sunnah, Jilid 1, (Beirut: Dar al-Fikr, 1983)

Yusuf Qardawi, Fiqhuz Zakat, Beirut, Libanon: Muassasat ar-Risalah, cet. 2, 1973, dalam Edisi Indonesia Hukum Zakat, (Jakarta: Litera Antar Nusa, cet. 9, 2006).

Zainuddin al-Malibari, Fath al-Mu'in, jilid 2, (Kudus: Menara, 1979). 